\title{
EN TORNO A LAS REPRESENTACIONES DE LA VENTA DE PERIÓDICOS EN ESPAÑA, 1836-1936
}

\author{
ABOUT THE REPRESENTATIONS OF THE SALE \\ OF NEWSPAPERS IN SPAIN, 1836-1936
}

\author{
Víctor Rodríguez Infiesta* \\ Universidad de Oviedo, España
}

\begin{abstract}
RESUMEN: Análisis de las representaciones de los vendedores de publicaciones periódicas a través de los contenidos de la prensa y otros impresos. Desfavorecidos socialmente, estos trabajadores son a menudo representados de forma negativa, ya sea por su pobreza, su insignificancia o la ausencia de escrúpulos cuando se trata de sobrevivir. La imagen que se difunde contrasta con el lugar central que ocupan en el sistema informativo, llegando a actuar como una forma de comunicación paralela o complementaria a los contenidos escritos de la prensa. En cierto modo, los vendedores son heraldos de una nueva época en la que la información periódica y la opinión pública juegan un papel esencial. Considerados en estas páginas como mediadores culturales, se plantea aquí su imagen pública como fruto de la tensión existente entre los espacios en los que se producen los contenidos de la prensa y el público, en el que influyen a diario.
\end{abstract}

PALABRAS CLAVE: Prensa, España, distribución, representaciones, siglos XIX y XX.

ABSTRACT: The representations of newspaper vendors are analyzed here through the contents of the press and other printed matter. Socially disadvantaged, these workers are often represented negatively, either because of their poverty, their insignificance or the lack of scruples when it comes to survival. The image that is disseminated contrasts with the central place they occupy in the information system, coming to act as a form of parallel or complementary communication to the written contents of the press. In a way, sellers are heralds of a new era in which periodic information and public opinion play an essential role. Considered in these pages as cultural mediators, their public image is raised here as a result of the tension between the spaces in which the contents of the press are produced on the one hand, and on the other the public in which they influence daily.

KEYWORDS: Press, Spain, distribution, representations, 19th and 20th centuries.

* Correspondencia a: Víctor Rodríguez Infiesta. Universidad de Oviedo. Departamento de Historia. C/ Amparo Pedregal s/n (Campus del Milán), 33011 Oviedo - rodriguezvictor@uniovi.es - https://orcid.org/0000-0001-7853-7789

Cómo citar: Rodríguez Infiesta, Víctor (2021). «En torno a las representaciones de la venta de periódicos en España»; Historia Contemporánea, 65, 41-73. (https://doi.org/10.1387/hc.20948).

Recibido: 22 junio, 2019; aceptado: 12 septiembre, 2019.

ISSN 1130-2402 — eISSN 2340-0277 / (C) 2020 UPV/EHU 


\section{Introducción}

Estas páginas se ocupan de la venta callejera de prensa desde una aproximación histórica y cultural que es entendida como historia social de las representaciones, al modo de Pascal Ory; prestando una atención especial a lo que Thibaut Le Hégarat ha señalado recientemente como puntos de contacto entre historia de los medios e historia cultural: estudio de contenidos, de las prácticas, las representaciones mediáticas del mundo social e historia de la cultura mediática. ${ }^{1}$ No es, en cambio, objeto de este estudio un análisis estrictamente social y mucho menos cuantitativo de la distribución, entre otras cosas porque la consabida pérdida de la mayoría de los archivos periodísticos del siglo XIX hace que sólo excepcionalmente, como hizo en su momento Jean-François Botrel con Madrid Cómico, sea posible acceder a los mismos y reconstruir con una precisión que sigue resultando excepcional la distribución de periódicos y revistas. ${ }^{2}$ Sólo indirectamente, y de forma fragmentaria a veces, podemos percibir la evolución general, a través de factores necesarios para el desarrollo de la prensa (técnicos, transportes, publicidad, demográficos, educacionales, etc.), del crecimiento del mercado periodístico, o analizar la evolución de las tiradas, con todas las dificultades propias de las fuentes en el caso español. ${ }^{3}$

En cualquier caso, a priori las representaciones de la venta de prensa parecen corresponderse poco con la centralidad que ésta ocupa en el sistema informativo. Y lo más importante es que del proceso de marginación del que son víctimas quienes se ocupan de esta actividad es también deudora una parte de - no toda - la historiografía sobre historia de la prensa. Los encargados de la venta son en gran medida marginados, sectores subalternos podría decirse, entendiendo este término en un sentido amplio ligado a la subordinación; ${ }^{4}$ sectores cuya palabra rara vez llega a nosotros directamente, sino mediada por otros actores. Voces que también en los documentos aparecen subordinadas. ${ }^{5}$

1 Ory, 2007, p. 13; Le Hégarat, 2019.

2 Botrel, 1982.

${ }^{3}$ Iglesias, 1996; Botrel, 2002. De la evolución cuantitativa de la prensa española se han ocupado distintos autores: C. Almuiña, J. L. Guereña, J. F. Botrel, M. Cabrera, A. Elorza y S. Castillo...

${ }^{4}$ Salvando las distancias del objeto de estudio, subordinación en términos de: «class, caste, age, gender and office or in any other way» (Guha, 1988, p. 35).

5 Tenti, 2012. 
Rara vez aparecen en los escritos destinados al gran público referencias al poder de los vendedores, a la posición como factor imprescindible que ocupan en el sistema informativo. Esto es algo que tenemos que deducir mediante distintos rodeos o recurriendo a otro tipo de documentos, como la Ley de Imprenta de 1879, en la que se establecía que la publicación sólo se produce cuando ha comenzado el reparto. ${ }^{6}$ Uno de los elementos constitutivos de ese factor esencial para la vida urbana moderna que es la publicación de diarios y revistas es la distribución: una publicación periódica no es realmente una publicación periódica hasta que existe al alcance del público, es decir hasta el momento en el que es distribuida. Ello hace que el vendedor no sea un elemento marginal, como reflejan la mayoría de las representaciones, sino central, y de esta centralidad - aunque esté ausente del imaginario mediático - son conscientes los propios vendedores que la utilizan para presionar y para plantear las primeras huelgas ya desde que en los años sesenta del siglo XIX, cuando La Correspondencia de España populariza la venta callejera y los vendedores, niños en su mayoría, pese a ser tratados brutalmente, son capaces de hacer valer su importancia poniéndose en más de una ocasión de acuerdo para no acudir a por el periódico. ${ }^{7}$ La fuerza huelguística en este sector suele ser escasa a largo plazo, pero lo importante es que estos trabajadores son conscientes de su capacidad para bloquear el sistema informativo y que la realidad por ejemplo de las asociaciones y sindicatos, que se multiplican desde principios del siglo $\mathrm{XX}$, nos sitúa lejos de una imagen de los vendedores desarticulados, siempre víctimas, rodeados de miseria y en la frontera de la delincuencia; una imagen que debe confirmarse mediante documentación de época.

${ }^{6}$ Ley de Imprenta de 7 de marzo de 1879 (Gaceta de Madrid, 8 de enero de 1879). Desde planteamientos que no eran novedosos se indicaba, en el Título III, que para que existiera delito de imprenta «se necesita la publicación», considerando que ésta se realizaba cuando había comenzado el reparto, se había puesto a la venta, fijado en un paraje o lugar público, o enviado al correo. Otra vertiente de la cuestión puede ilustrarse a través de lo sucedido en Chile en 1910, cuando las empresas periodísticas argumentaron, ante la aplicación en Valparaíso de un decreto municipal que dificultaba grandemente la venta, que «suprimido el suplementero [vendedor de periódicos] el diario queda inédito y la libertad de prensa habría quedado de hecho suprimida» (Rojas Flores, 2006, p. 64).

7 Juan de Madrid, «La Correspondencia de España y su propietario Don Manuel María Santana», La Ilustración Española y Americana, 10 de mayo de 1870, pp. 151-153. 
Tampoco puede ser ajeno a un análisis de las representaciones de los vendedores el papel que el voceo juega como acto comunicacional, la percepción de sus prácticas, tal vez como mass media, o de naturaleza mestiza, términos que se han apuntado para los ciegos vendedores de impresos y los pliegos de cordel. ${ }^{8}$ Nos encontramos ante una puesta en escena de la escritura transmitida frecuentemente mediante la oralidad, por lo que cabe preguntarse cómo se percibe la relación entre estas dimensiones, a las que a veces se añade lo visual. También interesarse por la capacidad del vendedor para interpretar el periódico, cuyo contenido asimila, quizás haciéndolo suyo, no mostrándose el vendedor semejante al periódico, sino haciendo que el periódico se asemeje al vendedor. Se establecería, en este caso, un pulso entre las élites de las que emanan los escritos, legítimas detentadoras de la capacidad para interpretarlos, y cualquier otra lectura, que se convierte en inadecuada respecto al verdadero sentido del texto. ¿Sería, entonces, el vendedor, un lector más, cuya lectura sin embargo se multiplica a través del voceo? Tal vez, en ese caso, estas prácticas supusieran una grieta en la construcción de un muro de significado que emana de la jerarquización social, ocultando con algunas lecturas ortodoxas la infinita pluralidad de significados que se corresponden con un inmenso número de lectores potenciales. ¿Es el vendedor un furtivo, como lo es el lector para Michel de Certeau, con el agravante de que la actividad del primero, su capacidad transgresora, es pública y particularmente influyente? ${ }^{9}$

Partiendo, en cualquier caso, de la hipótesis de que el vendedor es un mediador cultural, el objetivo de este trabajo consiste en aproximarse a cómo se perciben en la época las prácticas de venta de prensa en el espacio público, a la capacidad de quienes se ocupan de esta actividad para hacer visible el mensaje periodístico, actuando como intermediarios y añadiéndole significado, incluso, quizás, para ser vehículo de falsedades, conscientes de que éstas están ausentes del impreso, mucho antes de que habláramos de fake news. Para ello se ha realizado principalmente un vaciado de fuentes hemerográficas y de bibliografía contemporánea desde los años treinta del siglo XIX hasta las primeras décadas del XX, no desdeñando en absoluto las fuentes literarias, elementos esenciales cuando se trata de reconstruir representaciones.

\footnotetext{
8 Botrel, 1993, 1.2.; Fernández, 2000.

9 Véase Certeau, 1990, pp. 239-255, en cuya lectura, evidentemente, se inspiran estas últimas reflexiones.
} 


\section{La venta callejera}

Desde la segunda mitad del siglo XIX se desarrolla en España un sistema de distribución y venta de prensa que será cada vez más eficaz en un país en el que, pese a las limitaciones, la demanda de lectura no deja de crecer. La existencia de un número elevado de analfabetos (todavía un $63,8 \%$ de analfabetismo bruto en $1900^{10}$, aunque con comportamientos provinciales, urbanos y por sexo claramente diferenciados tras esta cifra) hace que resulte más interesante la aproximación al impreso desde una perspectiva amplia en la que se contemple la recepción de textos e imágenes a través de la mediación que supone la oralidad o la exposición más o menos desordenada de publicaciones periódicas en el espacio urbano contemporáneo. ${ }^{11}$ Con ello no sólo se alcanza a un público nuevo en un contexto en el que se generaliza la difusión del impreso, no limitándose al círculo de los lectores de la publicación, también se introducen matices en el mensaje original que en algunos casos pueden llegar a distorsionarlo.

A partir de unas prácticas que se remontan atrás en el tiempo y que enlazan con la venta por suscripción o al número por medio de ciegos o libreros y en puestos, en la segunda mitad del siglo XIX la venta callejera se desarrolla con el protagonismo de Las Novedades y sobre todo de La Correspondencia de España ${ }^{12}$. Ossorio y Bernard, siempre interesado en las cuestiones relacionadas con la venta de prensa, escribía en 1897 que

en el siglo último, la congregación religiosa de Ciegos tenía el privilegio de la venta de papeles; pero sus individuos no debían satisfacer mucho las exigencias del público, cuando los libreros les disputaron la citada venta. El nacimiento de la prensa noticiera hizo cambiar por

10 Datos del Censo de población de $1900.56,2 \%$ de analfabetismo neto (población de más de diez años).

11 Aunque la bibliografía sobre el analfabetismo sea relativamente amplia, cabe remitir al menos a dos obras clásicas: Escolano Benito (dir.), 1992; Vilanova Ribas y Moreno Juliá, 1992. Un acercamiento sintético a las prácticas de lectura y a la incidencia de la cultura escrita en los no alfabetizados en: Martínez Martín, 2005; Botrel, 2015. Para la historia de la lectura en general: Infantes, López, Botrel (dirs.), 2003; Martínez Martín (dir.), 2001.

12 Seoane, 1983, pp. 203, 247; Martínez Fernández, 2000, pp. 113-116. Ver también: Juan de Madrid, «La Correspondencia de España...», La Ilustración Española y Americana, 10 de mayo de 1870 . 
completo el aspecto de esta industria, y desde que la guerra de África hizo la fortuna de algunos periódicos, éstos tuvieron, en los vendedores ambulantes, unos poderosísimos auxiliares $[\ldots]^{13}$

De acuerdo con estas apreciaciones, por lo tanto, y aunque existieran precedentes dignos del mayor interés, este tipo de comercialización, ambulante y callejera, comenzaría a generalizarse realmente en la España del siglo XIX desde finales de los años cincuenta e inicios de los años sesenta. ${ }^{14}$ La Hermandad de Ciegos de Madrid había sido disuelta por un decreto de enero de 1836, firmado por Salustiano Olózaga. ${ }^{15}$ Ya en decadencia, víctima de los nuevos tiempos, de la libertad económica, de una producción de impresos más abundante y moderna, sin embargo sus actividades sobreviven y aún en 1852 el Gobernador civil de Madrid, Melchor Ordoñez, encabezaba así una serie de disposiciones sobre la venta de periódicos, folletos y otros impresos:

Ha llamado mi atención el abuso que se observa en los expendedores de impresos que van pregonando por las calles de la corte. Admitido como regla en este punto que sólo se dediquen a esta industria los ciegos o personas que tienen algún defecto físico el cual les impida dedicarse a los demás trabajos en que pudieran ganarse la subsistencia, se ven sin embargo en el día ocupadas en esto personas sanas y útiles para toda clase de trabajos, lo cual prueba su poca afición a éstos, y es poderoso aliciente para la vagancia. ${ }^{16}$

13 Manuel Ossorio y Bernard, «Notas periodísticas», La Correspondencia de España, 12 de julio de 1897.

14 R. Sepúlveda (1872, pp. 39-49), tras indicar que «los ciegos hacían antes el gasto», añadía lo siguiente: «hay quien asegura que más adelante El Guirigay fue el primer periódico que se vendía de contrabando, acercándose el expendedor misteriosamente al transeúnte»; una técnica que, «afirman algunos», seguiría también Fray Gerundio. «Sin embargo, el primer periódico que se vendió en Madrid públicamente en la Puerta del Sol, fue Las Novedades», y después «La Correspondencia de España, cuando de autógrafa se convirtió en tipográfica». Alude también el autor a los periódicos satíricos que comenzaron a seguir esta tendencia.

15 Sobre la vida de la hermandad y las causas de su desaparición: Botrel, 1993, 1.1. Para la evolución posterior de la venta de impresos por ciegos también: Fernández, 2000. Un repaso a la bibliografía sobre el ciego callejero en la España de la edad moderna, época que no será objeto de atención específica en estas páginas, en: Iglesias Castellano, 2016.

16 Boletín Oficial de Madrid, 26 de febrero de 1852. Más adelante se trataría de volver en algún caso a tiempos pasados regulando la venta. Al decir de la prensa (El Imparcial, 5 y 10 de abril de 1884; El Globo, 8 de abril de 1884) un bando del Gobernador de Sevilla prohibía la venta de periódicos y billetes de lotería excepto a «los ciegos, los ancianos y los inútiles». 
Al tiempo que los vendedores ambulantes ocupan progresivamente las calles, se mantiene la venta en puestos, uniéndose a los mismos a partir de 1860 en Madrid los primeros quioscos de periódicos, ${ }^{17}$ espacios que más adelante se convertirán en el lugar privilegiado para la venta de diarios y revistas, pero que en estos momentos comparten sus funciones con otras actividades, vendiéndose en los mismos distintos objetos y sirviendo durante mucho tiempo también para otro tipo de escrituras expuestas: los anuncios. ${ }^{18}$

La prensa se vende, además, en una amplia y variada gama de establecimientos, incluidas tiendas de ultramarinos y otros comercios. En todo caso, los quioscos y puestos como puntos de venta especializados están ya bien consolidados en las primeras décadas del siglo XX, cuando puede aludirse ya sin duda a un sistema de distribución complejo y bien organizado. ${ }^{19}$ Dejando de lado a los repartidores a domicilio, que se ocupaban de las suscripciones, existía ya una red de distribución compleja y con múltiples ramificaciones por todo el país, en la que el corresponsal administrativo ocupaba un lugar fundamental. ${ }^{20}$ La aparición en 1914 de la Sociedad General Española de Librería (SGEL) y sus librerías de ferrocarril es un buen indicador de las expectativas que podían abrirse a gran escala en el sector. ${ }^{21}$

En la capital de España, además de en las administraciones de los propios periódicos, la distribución se organizó en La Puerta del Sol y a partir de los años diez en la cercana Plaza de Pontejos, tratando también de llevarse durante un tiempo a la Plaza Mayor. Tenían aquí su punto de encuentro los capataces, corredores y sus subordinados, que se ocupaban de recorrer las calles para depositar los diarios y después recoger los ejemplares no vendidos. ${ }^{22}$ Finalmente estaban los propios vendedores, a su vez

17 Archivo de Villa, Madrid, Inventario de Secretaría, Libro XVI, Comercio e industria, 1410-1898, p. 280.

18 Para una aproximación a otro tipo de relaciones con el terreno de la publicidad puede verse: Fernández Poyatos y Feliu García, 2012; Feliu García y Fernández Poyatos, 2012.

19 Véase: Rodríguez Infiesta, 2016.

20 Una descripción tanto de la organización de las suscripciones como de los corresponsales, desde el punto de vista del periódico, en Mariné, 1929.

21 De la relaciones entre impresos y ferrocarril se ha ocupado recientemente en una parte de su tesis doctoral: González Jurado, 2015, y también en: 2014. En particular sobre la Sociedad General Española de Librería: Martínez Rus, 2003, así como las memorias de Manuel Aguilar (1972), manejadas por esta autora.

${ }^{22}$ La Voz, 18 de mayo de 1927, La Gaceta Literaria, 1 de agosto de 1927, ABC, 27 de abril de 1934, 7 de mayo de 1912; Mariné, 1929. 
jerarquizados y divididos en categorías internas. No podía ser lo mismo, evidentemente, ser propietario o usufructuario de un quiosco que instalarse de forma más o menos precaria en un puesto o dedicarse a la venta itinerante. ${ }^{23}$ Respecto a estos últimos, los vendedores y vendedoras ambulantes, situados en los lugares más bajos de esta escala y en general de la sociedad, hay que comenzar por preguntarse quiénes eran realmente.

Ricardo Sepúlveda señalaba en Los españoles de hogaño (1872) que se trataba fundamentalmente de «chicos desarrapados, mozos holgazanes, gente de mal vivir, en una palabra, que lo mismo venden un periódico que extraen un reló, sin dolor; ayudantas de los tomadores del dos, viejas viciosas...». Tal vez, a veces, «un mocetón, robusto y coloradote, que, poco hábil o bastante holgazán para dedicarse a otro trabajo, prefiere esta casi-ocupación [...], logrando así vivir sin trabajar, porque no creo que haya quien sostenga que es una profesión o un oficio eso de vender periódicos». Con más ternura aludía el autor a los «muchachos de cinco o seis años que en un punto determinado, tiritando de frío en las crudas noches de invierno, venden periódicos dando voces apenas perceptibles», o a las «mujeres ancianas, viejos valetudinarios, pobres cesantes y otras víctimas de la desgracia» que lograban subsistir por este medio. Y a aquellos mismos o a otros niños similares, expuestos «a ser atropellados a cada momento», sin lograr atraer la atención de los transeúntes, se refería José González de Tejada en una colección de artículos publicada el mismo año:

Muchachos que andan por el mundo como los pajaritos, sin conocer tal vez a su padre ni a su madre, y durmiendo con la cabeza bajo el ala, o sea sobre el hombro, en el hueco de la primera puerta en la que les coge el sueño, mujeres que por el traje y no por la cara lo parecen, niñas, pobres criaturas a quien sus madres enseñan esa miserable vida, para que luego ellas acaso aprendan otra más miserable todavía, he aquí los seres que se encargan de extender el renombre, la fama de políticos y literatos, de artistas y de banqueros, de industriales y de actores. ${ }^{24}$

${ }^{23}$ Disparidad que aparece incluso en el modo de suscribir un documento, en el caso de una misiva dirigida al Director General de Seguridad, desde las firmas sin otra indicación, algunas titubeantes, hasta las que se acompañan con soltura del nombre del quiosco o puesto, o la presencia de sellos en el caso de dos quioscos. S.f. (probablemente década de 1930), Archivo General de la Guerra Civil Española (AGGCE), PS-Madrid, C. 509, Exp. 237.

${ }^{24}$ González de Tejada, 1872, pp. 38-44. 
Tenemos, con estas descripciones, apoyadas por otros testimonios, una ocupación que sitúa inmediatamente a los vendedores y vendedoras en un espacio marginal, en algún lugar entre la mendicidad y la delincuencia. Vender periódicos ni siquiera es considerado un trabajo, aunque no todas las visiones de los vendedores sean tan severas en aquellos momentos,$^{25}$ y más adelante se reconocería lo penoso de una labor que, como se recogía en algunas revistas ilustradas en las primeras décadas del siglo XX, se desarrollaba en jornadas de trabajo interminables, iniciadas por lo general en torno a las seis de la madrugada para concluir a veces a la una o las dos de la mañana del día siguiente, tras un descanso al final de la tarde, vendiendo los diarios de la noche a la salida de los teatros. ${ }^{26}$

José Fernández Bremón ponía en 1885 las siguientes palabras en boca de «la niñez desamparada» que vendía periódicos: «¿Llamas vagancia a un ejercicio fatigoso, como es este comercio al por menor? ¿Dices que carezco de oficio, cuando aprendo el arte difícil de vender, que es una profesión en que se exigen actividad e inteligencia? ¿Seré menos vago si me quitas el oficio que ahora ejerzo? ${ }^{27}$ Pese a todo, la vinculación de la venta de prensa a la falta de honradez o a la marginalidad extrema sigue presente en la mente de no pocas personas durante mucho tiempo, como reflejan la prensa, la literatura o algún testimonio personal. ${ }^{28}$ Pero también es cierto que al avanzar el siglo XX se repiten los escritos que insisten en relegar esta visión al pasado y ofrecer una imagen más respetable de la venta ambulante, a la que recurren por ejemplo obreros que teniendo otras ocupaciones se dedican a la venta de prensa durante unas horas para «sumar unas pesetas al diario jornal». ${ }^{29}$

Se desprende, además, de los textos citados más arriba, una imagen general de las personas que se ocupaban de esta actividad. Como sucedía con la mendicidad, no parecía aceptable que los adultos que disfrutaban de buena salud y no sufrían ningún tipo de incapacidad física se dedica-

${ }^{25}$ Cfr., por ejemplo, Juan de Madrid, «La Correspondencia de España...», La Ilustración Española y Americana, 10 de mayo de 1870, pp. 151-153.

${ }^{26}$ Equis, «El periódico en la calle», Nuevo Mundo, 3 de septiembre de 1903; Miguel Medina «Los vendedores de periódicos», Alrededor del Mundo, 24 de junio de 1918.

27 José Fernández Bremón, «Los vendedores de periódicos», El Liberal, 26 de septiembre de 1885 .

28 Véase: Rodríguez Infiesta, 2011.

${ }_{29}$ V. Gutiérrez de Miguel, «El vendedor callejero de periódicos en Madrid», La Voz, 18 de mayo de 1927. Fernández Bremón («Los vendedores...»), apuntaba en similar dirección ya en 1885 . 
ran a la venta de periódicos. Nuevamente esta percepción evolucionaría con el tiempo, pero se conservaba por esta vía el recuerdo de las épocas en las que la venta callejera estaba en manos de ciegos, alimentándose posteriormente la venta de periódicos no sólo de invidentes sino también de quienes, a causa de algún impedimento físico, tenían dificultades para desempeñar otro trabajo, de ancianos necesitados de algunos ingresos o de personas que habían caído por diferentes motivos en una situación de miseria extrema. A esto se unía un gran número de niños y niñas en mayor o menor medida desamparados, algunos de muy corta edad, que generaron una visión estereotipada, difundida por la literatura y el cine: la del pilluelo avispado y por lo general simpático que ha desarrollado todo tipo de habilidades para sobrevivir en un mundo hostil.

Las vendedoras también constituyen un caso aparte, al sufrir una doble discriminación: social, al ser asimilada la venta casi a la indigencia, y a causa de la propia condición femenina de las vendedoras, a las que a menudo se relacionó con la prostitución, sin duda por la propia falta de recursos materiales y por estar obligadas a tratar con cualquier desconocido que se les acercara en medio de la calle, facilitándose de este modo la conversación o las proposiciones de todo tipo. A «mujeres, que buscan pretexto para otros fines en la venta de periódicos» se refería un vendedor en 1913; a «jovencitas que utilizan la venta de periódicos con otros fines» se aludía en 1922 en relación con una orden del Director General de Orden Público; y, en el artículo citado más arriba, El Sol daba por sentado «las consecuencia que irradia, por ejemplo, dedicar a una niña a menesteres de la calle - venta de periódicos, lotería, tabaco, etc. $\longrightarrow \gg .{ }^{30}$ Por supuesto, a veces la venta de prensa fue usada como simple tapadera. ${ }^{31}$ Pueden rastrearse otros vestigios de ello, como el que ofrece Pío Baroja en un capítulo de La Busca, al referirse a «una cuadrilla de muchachas, de trece a diez y ocho años, que merodeaban por la calle de Alcalá, acercándose

30 «Los vendedores de periódicos», El Siglo Futuro, 19 de agosto de 1913; «El director de Orden público y los vendedores de periódicos», La Acción, 4 de julio de 1922; «La explotación de los niños», El Sol, 9-2-1932. El propio R. Sepúlveda, en la obra citada, se refería a los jóvenes que comenzaban vendiendo periódicos para, ellos, convertirse en ladrones («tomadores del dos») y ellas entrar «muy pronto en el camino de la prostitución». Y a los peligros que corren lo que denomina «niñas vagabundas», aquellas que, entre otras actividades, «venden fósforos, palillos para los dientes, frutas, flores, periódicos»..., le dedicaba también su atención Sofía Tartilán en 1877, pp, 81-87.

${ }^{31}$ Representándose su vinculación a actividades ilegales en diferentes contextos y países. Véase como ejemplo, para el caso mexicano y los niños voceadores: Gutiérrez y Gantús, 2013. 
a los buenos burgueses, fingiéndose vendedoras de periódicos y llevando constantemente un Heraldo en la mano». ${ }^{32}$ Sin embargo los espacios de intersección podían afectar también a quien en modo alguno tenía intención de comerciar con su cuerpo, sobre todo si practicaba - aunque fuera sin saberlo - la venta de publicaciones eróticas. Así describía Antonio Díaz Cañabate la respuesta de una vendedora a un compañero de oficio sorprendido por el hecho de que aquella se negara a vender una publicación sicalíptica muy demandada:

Tú eres hombre y los hombres tenéis bula. Yo cogí los primeros números de La Hoja de Parra porque no sabía lo que era, porque ni por curiosidad reparé en los dibujos que tenía dentro, pero un día se me acerca un viejales asqueroso y me compra La Hoja y la abre y me enseña a una tía pindonga en camisa, y me dice al oído: «Si me dejas verte así, te doy cinco duros» ${ }^{33}$.

Los indicios de la posición social de las personas que se ocupan de la venta son muy abundantes, contribuyendo a paliar su situación sólo en parte distintas iniciativas, a veces ligadas entre sí, como la actividad societaria, la creación de montepíos (en Madrid y Barcelona) o la inauguración en la carretera de Chamartín de una Casa del Vendedor poco antes de la Guerra Civil con, entre otros servicios, habitaciones para ancianos o personas imposibilitadas de trabajar. ${ }^{34} \mathrm{La}$ miseria y el desamparo, parece ser que acentuados a medida que remontamos el hilo del tiempo, fueron características comunes sobre las que, como señalaba González de Tejada, se asentaba el brillo de quienes alcanzaban notoriedad gracias a la prensa.

No es necesario extenderse más en una cuestión que constituye una característica compartida en distintos países, en no pocos casos presente hasta hoy en día. Pero sí debe tenerse esta característica muy presente porque es a todas luces una de las claves para comprender el rechazo y el temor que despierta la actividad de la venta en la calle en determinados sectores de la sociedad, haciendo que los mensajes lanzados por las élites culturales y políticas sigan cauces a veces insospechados y de algún modo pasen por el filtro de un pequeño ejército de marginados.

\footnotetext{
${ }^{32}$ Baroja, 1973 [1904], p. 246.

33 Díaz Cañabate, 1968, p. 14.

34 Véase, por ejemplo: Crónica, 22 de julio de 1934; El Heraldo de Madrid, 4 y 30 de mayo de 1935, 23 de marzo de 1936; La Libertad, 20 de abril de 1935 y 2 de junio de 1935.
} 


\section{Escritura visible, escritura audible}

Frente a un sistema de distribución en el que la suscripción pueda ser el procedimiento casi único o predominante, como sucedió en algunas épocas, la venta en la calle constituye una vía de comunicación paralela a la contenida en el propio periódico, ligada a ésta pero en gran medida autónoma. Los quioscos, puestos y vendedores ambulantes, en algún caso también otros establecimientos, se convierten en espacios de difusión de la cultura escrita en los que, en busca del comprador, se alcanza a un sector mucho más amplio de la población. Se exponen textos e imágenes en bastidores, se muestran en las manos del propio vendedor o por otros medios, y se ponen en la calle informaciones a través de mensajes orales que inundan la ciudad contemporánea mediante el voceo. De este modo los contenidos procedentes de la prensa se prolongan en el espacio urbano alcanzando a alfabetizados e iletrados, a quienes los reciben con agrado y a quienes desearían permanecer al margen de los mismos, a los destinatarios iniciales y a aquellas personas que, según unos códigos morales aceptados por gran parte de la sociedad, deberían mantenerse totalmente al margen de determinadas publicaciones. La prensa católica se queja frecuentemente, por ejemplo, de «tanta revista obscena, tanto folleto escandaloso, tanta fotografía impúdica como se ostenta a las narices de todo el mundo, para que, a quieras o no quieras, el niño, la joven y el hombre horados tropiecen con sus indecentes figuras» ${ }^{35}$.

En este «a quieras o no quieras» está probablemente una de las claves explicativas de las distintas medidas represivas que se aplicaron a los vendedores. Los mensajes como el anterior se lanzaban generalmente contra quioscos, puestos y librerías; pero también los vendedores ambulantes exponían a menudo una parte de su mercancía a la vista del público mediante un gesto que admitía alguna variante, apoyando el grueso de los ejemplares en el antebrazo y mostrando una o varias primeras páginas. En los momentos en los que no fue posible pregonar el título del periódico o su contenido, esta forma de publicidad adquiría, evidentemente, la mayor importancia.

El voceo, las imágenes y los textos expuestos contribuyen a la generalización de informaciones relacionadas con la marcha de los asuntos públicos, los gobernantes, la política o la sociedad, dejando algún tipo de

35 La lectura dominical, 3 de junio de 1894. 
huella incluso en aquellas personas que en principio pudieran verse menos inclinadas a interesarse por tales cuestiones. En realidad la prensa se había instalado ya en la vida cotidiana como una segunda piel, tiñendo con su presencia, a través en gran parte de la venta callejera, el día a día de la población urbana; insertándose en la misma como un acompañante inevitable, a veces no deseado:

Cuando abrís los ojos a la luz del día la primera palabra que llega a vuestros oídos es el nombre de un periódico; si trabajáis en vuestro despacho, milagro será que en un alegato, en una poesía o en una carta de pésame no escribáis sin pensarlo el título de El Gil Blas de El Cascabel o de El Cencerro, que repite sin cesar y sin descanso una mujer o un chiquillo en la esquina de enfrente. Los vendedores de periódicos, en fin, os hacen conocer en caricatura a todos los personajes políticos a fuerza de ponéroslos delante en la calle, y aunque os encerréis en casa, os tienen al corriente de qué partido ha dado un manifiesto, o del punto de España en el que ha habido ocurrencias; lo mismo al aire libre que en el hogar doméstico, por la mañana, por la tarde, por la noche, a todas horas y en todas partes no podéis menos de ver a los vendedores de periódicos o de oír sus gritos ${ }^{36}$.

Comienza a vivirse al ritmo del diario ${ }^{37}$, y se establecen cadencias a menudo relacionadas con la venta callejera, convirtiéndose ésta en un instrumento para la medida del tiempo que una vez más no influye únicamente, ni mucho menos, en los lectores de publicaciones periódicas. No se trata únicamente de que la publicación salga de la imprenta y llegue a los suscriptores, aspecto este último importante aunque relativamente poco visible para el conjunto de los ciudadanos, es imprescindible que se ponga a la venta y a ser posible recorra las calles y alcance los oídos de toda la población. Su presencia, matutina, vespertina, semanal, es un síntoma de normalidad; es una de las razones por las que se hace todo lo posible para que la venta al número no se interrumpa cuando se produce una huelga. Y por el mismo motivo, unido, naturalmente, a la necesidad de transmitir determinados mensajes, la presencia de vendedores en las calles de un Madrid bombardeado durante la Guerra Civil se hace imprescindible y les convierte en héroes que llevan a los barrios más peligrosos «el alimento espiritual», señalaba Claridad en mayo de 1937, consiguiendo

\footnotetext{
36 González de Tejada, 1872, pp. 40-41.

37 Véase: Marie-Ėve Thérenty, 2011.
} 
también que «con sus pregones se parezca algo el Madrid de ahora al Madrid de hace meses, cuando todavía no se habían levantado en armas los honrados militares españoles». ${ }^{38}$

Sin embargo la venta y particularmente el acto del voceo tienen también en sí mismos algo de perturbador, pudiendo convertirse fácilmente en un grito de desafío o en un mecanismo de provocación del adversario, influyendo siempre en la opinión pública. En el terreno de la prensa anticlerical, cuya venta no estaba exenta de riesgos en la España de la época, es interesante el ejemplo del llamado vendedor del cencerro, encargado de comercializar el periódico del mismo nombre en el Madrid de principios del siglo XX. El hecho de gritar «iContra los frailes, que comen y no trabajan!», era ya de por sí todo un programa y una forma de condensar en unas palabras para el gran público lo que la publicación desarrollaba de forma mucho más detallada en su interior. Si a ello le añadimos una fisonomía y una vestimenta fácilmente reconocibles y el hecho de acompañarse con un cencerro de buenas dimensiones que, por supuesto, hacía sonar para llamar más la atención, tenemos que su presencia misma en el espacio público, aun cuando permaneciera en silencio o no mostrara su mercancía, era una forma de poner en escena aquello que hasta entonces permanecía encerrado en las páginas de la publicación. ${ }^{39}$

El título mismo de determinados periódicos era una provocación, un programa político y un grito de rebeldía que voceado en el espacio público podía convertirse fácilmente en bandera sediciosa, y otro tanto puede decirse de determinados subtítulos. La lista de cabeceras propicias a ello es muy amplia, desde La Lucha de Clases hasta La Conquista del Estado, pasando por El Motín y tantas otras revistas o diarios. En 1933, en San Sebastián, se producían peleas a causa de «la forma en que vocean sus respectivos semanarios los vendedores de «La Voz del Trabajo, socialista; Euzkadi Roja, comunista; El Fuerista, tradicionalista, y Sin Dios, órgano de la Liga atea». ${ }^{40}$ Tal vez al título de la publicación los voceadores añadieran otras

38 « ¡Salud, vendedores de periódicos!», Claridad, 15 de mayo de 1937, reproducido en: Boletín de la Sociedad de Vendedores de Periódicos El Progreso, agosto de 1937. En el artículo se alude a la niña vendedora Gloria González, fallecida en la calle al ser alcanzada por la artillería enemiga.

${ }_{39}$ Cfr. Díaz Cañabate, 1968, pp. 7-8; «El periódico en la calle», Nuevo Mundo, 3 de septiembre de 1903. Para el nombre del vendedor, Serafín Prieto, y sus problemas con la justicia: «Al gobernador», El País, 3 de abril de 1903.

40 La Libertad, 14 de mayo de 1933. Los enfrentamientos debían producirse reiteradamente. Véase: El Sol, 7 de mayo de 1933. 
consideraciones, pero no cabe duda de que la denominación de los periódicos citados era ya de por sí un estandarte. ¿Quién podía permanecer indiferente, por ejemplo, al último de los títulos, lanzado a voz en grito? ${ }^{41}$

Aunque existen desde mucho tiempo antes precedentes de reyertas por motivos políticos comenzadas a raíz del voceo de un periódico, el ambiente eléctrico vivido en algunos momentos durante la Segunda República contribuía sin duda a que se produjeran hechos como estos. Es en los años que preceden a la sublevación militar de 1936 cuando la distribución de prensa pasa a un primer plano, con numerosos atentados contra quioscos o puestos en 1933-1934 y una práctica de la venta callejera de publicaciones izquierdistas y falangistas que se convierte en un acto militante realmente peligroso, de primer orden. Se trata de una forma ritualizada de ocupación del terreno que lleva tanto a una representación extremada de la oposición entre determinadas cabeceras, y por supuesto de las organizaciones que están detrás de las mismas, como al proceso por el cual se proyectan en la calle a través de unos mecanismos de venta ambulante que disponen de sus propias prácticas propagandísticas.

Hay por lo tanto, en el voceo, algo de apropiación del territorio físico y mental, tanto del adversario como del lector, de disputa en torno a un espacio desde el que mostrar determinados mensajes. Sin embargo, la desconfianza que los vendedores despertaron en las autoridades y las distintas medidas tomadas repetidamente para reprimir el voceo estuvieron en la mayor parte de las ocasiones dirigidas a aquellas personas que se ocupaban de la venta de prensa por motivos pecuniarios. Casos como los citados más arriba pueden resultar muy ilustrativos, pero lo cierto es que la parte más sustancial de la producción impresa no circulaba a través de la venta militante, y que los vendedores que carecían de cualquier motivación ideológica para mostrar o vocear un diario en la calle tenían sus propios códigos de conducta y generaban unos mecanismos singulares de difusión a gran escala de la cultura impresa.

En primer lugar, el vendedor ambulante es un mediador que, además de vender el propio periódico, transmite una información cuyo origen está en principio en aquel, pero que a menudo recibe de otra persona que es quien conoce realmente el contenido. Con ello tenemos que, entre la información original y la recepción oral de quien escucha las noticias, pero

${ }^{41}$ Del impacto que podía causar tal voceo dejó constancia el escritor y militar franquista José María Gárate Córdoba: «Hace días oí pregonar un nuevo periódico cuyo título hace temblar como una blasfemia que desafiase al cielo; ¡Sin Dios, órgano de la Liga Atea!» (1972, p. 30). 
no lee la publicación, se han producido ya uno o dos procesos intermedios de recepción y transmisión, al que se une el propio oyente de la noticia voceada. «Casi ninguno de ellos saben leer ni escribir. Se enteran, preguntando en la redacción, de lo que trae el periódico o la hoja que les dan y pregonan el artículo variando su sentido o su objeto, unas veces intencionalmente para vender más y mejor, otras sin comprender lo que dicen». ${ }^{42}$ Con el tiempo, sin duda, el número de vendedores alfabetizados aumentó, manteniéndose de todas maneras en muchos casos el recurso al capataz, que informaba cuando había sucedido algo extraordinario, mientras «la mayor parte de los vendedores pegaban voces sin saber lo que decían». ${ }^{43}$

A partir de aquí, y una vez que cada vendedor recibía la cantidad de periódicos solicitada, se producía la salida atropelladamente, corriendo y voceando en gran número hasta que el diario se hacía visible y audible en toda la ciudad. La adición de voces y la sincronía del gesto contribuían sin duda a su eficacia, dándose también por esta vía una forma de ocupación del espacio público por el periódico. El caso de La Correspondencia de España, cuyo papel pionero en la venta callejera ya se ha mencionado, está bien documentado. Se alude en distintos momentos a una «carrera en vertiginosa competencia» que comienza en el edificio en el que la cabecera está instalada, a la «extensión en guerrilla por todas las [calles] de Madrid corriendo con toda la fuerza de sus talones [...]», a «irrupción» acompañada del anuncio a voces del periódico, a «avalancha» que se aproxima, a «tormenta» que «ha perdido todo su carácter de gravedad» al llegar a la Puerta del Sol. Es, en definitiva, un «diluvio de voces. Hay un momento en que se oye al mismo tiempo un solo grito en todo Madrid. iiiLa Correspondencia de España!!!». ${ }^{44}$

Si retrocedemos un poco en el tiempo, no dista mucho de las imágenes anteriores la que ofrecen los ciegos que esperan la salida de alguna gaceta extraordinaria a principios de los años cuarenta, para después diseminarse corriendo «como energúmenos, aturdiendo los oídos del pacífico ciudadano, y perdiendo de vender su género en fuerza de andar deprisa, y de los gritos

42 Ricardo Sepúlveda, 1872, p. 47.

43 «El periódico en la calle», Nuevo Mundo, 3 de septiembre de 1903; A. Díaz Cañabate, 1968 , p. 9.

44 José Fernández Bremón, «Los vendedores...», El Liberal, 26 de septiembre de 1885; Ricardo Sepúlveda, 1872, p. 44; Ossorio y Bernard, 2001, p. 99. Un grabado que representa el momento en el que los vendedores «parten como exhalaciones» de la administración del diario, en Juan de Madrid, «La Correspondencia...», La Ilustración Española y Americana, 10 de mayo de 1870, p. 153. 
de sus colegas, que tampoco querían hacer alto hasta que se apoderaran de una calle, donde campeasen solos» ${ }^{45}$. Y muchos años más tarde, cuando $L a$ Correspondencia de España ya había desaparecido, encontramos términos similares a los aplicados a aquella cabecera refiriéndose a otro diario vespertino, La Voz. La calle del diario «hierve», «se agita en una convulsión de río que se desborda» al iniciarse la salida, y finalmente comienza el voceo: «de todas partes llega como un eco de pregón que llena Madrid ¡La Voz!» ${ }^{46}$

Ahora bien, salvo en los momentos en los que esta práctica estuvo prohibida, se buscaba añadir al nombre del diario alguna información sobre su contenido, ya fuera la proporcionada por el capataz o aquella que el vendedor juzgaba más oportuna para aumentar la venta. El voceador con olfato buscaba el tono y las palabras adecuadas para hacer atractiva su mercancía, abusándose durante mucho tiempo de las «Informaciones horripilantes. «La mujer degollada», «Las niñas desaparecidas», «El hijo desnaturalizado que degolló a su padre sin causa justificada»». ${ }^{47}$ Aquí, y en la elección misma de los periódicos mostrados y pregonados, residía su capacidad para dejar cierta impronta en el mensaje lanzado a los cuatro vientos. Y ello es aplicable a cualquier otro proceso que implique una transmisión oral condensada y sesgada de los contenidos impresos de un diario. El voceador al que Díaz Cañabate atribuye sus informaciones aseguraba que en los cafés madrileños en los que era posible la venta:

No se podía vocear, pero sí ofrecer el papel por lo bajines con el crimen o lo que fuera. Yo los días de crisis me empapaba bien de todo lo que decían los políticos y los periodistas. Y me iba a un café. Y me acercaba a una mesa y decía con algo de misterio: «El Parlamentario con las declaraciones verídicas de Romanones en las que dice que don Segismundo Moret está mochales» En otra mesa anunciaba que don Melquiades Álvarez era ya más monárquico que el rey. Y la gente picaba y yo vendía el triple que mis compañeros ${ }^{48}$

45 Ferrer del Río y Pérez Calvo, 1844.

46 V. Gutiérrez de Miguel: «El vendedor...», La Voz, 18 de mayo de 1927. Una imagen ilustrativa en fechas cercanas, tomada de la cabecera barcelonesa El Diluvio (extraordinario del 10 de febrero de 1929), reproducida en la cubierta y comentada en: Gómez Mompart, 1992, pp. 117-118.

47 Díaz Cañabate, 1968, pp. 5-6; Lázaro Somoza Silva: «Los vendedores de periódicos y su casa, que será sanatorio, círculo y biblioteca», La Libertad, 20 de abril de 1935. V. Gutiérrez de Miguel, «El vendedor...», La Voz, 18 de mayo de 1927

48 Díaz Cañabate, 1968, p. 16. 
La técnica para atraer la atención y la escala eran distintas, pero el tamiz deformador del interés personal o el sesgo popular de sus palabras estaban igualmente presentes.

A esta visión de los contenidos de la cabecera se superponía un segundo nivel de distorsión cuyo origen está no necesariamente en el deseo de vender más periódicos, sino en el desconocimiento de lo que éstos contenían o habían contenido en el pasado. Ambas cuestiones estaban presentes en el retrato del ciego que entre otras cosas vende «gacetas extraordinarias, periódicos y hojas volantes», firmado en 1844 por Antonio Ferrer del Río y Juan Pérez Calvo en Los españoles pintados por sí mismos:

¿quién no recuerda haberle oído pregonar el año de 36 la muerte de Fernando VII, cuando de lo que hablaba el papelito nuevo, era de las honras a la muerte del rey? ¿Quién no le ha visto vender por dos cuartos la muerte de Riego y los suyos por el año 40 en que se exhumaban los restos del mártir de la libertad? Y es que el pobre Ciego atento a la ganancia, después que un muchacho le ha leído el papel, lo glosa procurando conciliar las circunstancias con su propio interés. ${ }^{49}$

Más adelante, cuando a la venta ambulante de periódicos y otros impresos se dedicaban ciegos y no ciegos de forma habitual, no parece que las cosas hubieran cambiado mucho. En 1872 podían leerse las siguientes palabras en otra obra costumbrista: « ¿Cuántas veces ha caído el público en la red comprando una hoja o un extraordinario, donde, según el vendedor, había una noticia interesante...! ¡Cuántas también ha oído destrozar títulos de artículos y nombres de personajes! Recuerdo que hace poco tiempo, una vieja decía en la Puerta del Sol, al vender una hoja, en que se hablaba de los asesinos del general Prim: -Señorito, $;$ los asesinatos del general Prim! En dos cuartos.»50

$\mathrm{Si}$ a estos ejemplos de algo que debió ser relativamente frecuente añadimos otras variantes en las que la falsedad de la noticia adquiere todo el protagonismo, se hace aún más evidente la relevancia del vendedor ambulante de periódicos y otros impresos. Como ya sabemos, los vendedores se enteraban del contenido del periódico preguntando en la

49 Ferrer del Río y Pérez Calvo, 1844, p. 477. Otras referencias a la deformación de informaciones en Botrel, 2000; Fernández, 2000.

50 Sepúlveda, 1872, pp. 47-48. 
redacción y después lo pregonaban «variando su sentido o su objeto, unas veces intencionalmente para vender más y mejor, otras sin comprender lo que dicen ${ }^{51}$.

Ahora bien, también cabía ir más allá y, sin otro fundamento que la necesidad de aumentar la venta, crear una noticia sensacional, tan ausente de las páginas del periódico como de los hechos del día. Aludiendo a casos sucedidos en París y Roma, un diario barcelonés señalaba en 1888 que se trataba de una «treta que suelen emplear también los vendedores en España ${ }^{52}$. Y la misma cabecera indicaba en primera página en 1893 que «los vendedores de periódicos sembraron ayer la alarma en las calles de Barcelona vendiendo a voz en grito una falsa última hora con «la muerte del señor Cánovas del Castillo»». Se trataba en aquella ocasión del eco de un rumor que habían recogido todos los periódicos madrileños y que no puede atribuirse a la iniciativa de los vendedores, pero que muestra el papel central que en la escenificación del acontecimiento juega la propagación repentina y «a voz en grito» de un suceso, provocando que en cuestión de minutos la casa del líder conservador catalán Manuel Planas y Casals se viera invadida por grandísimo número de personas preguntado por la exactitud y detalles de la información, y que «empezaran a llover cartas y tarjetas» en el mismo sentido. ${ }^{53}$

Los errores o en alguna ocasión el pregón de noticias no contenidas en el diario, siguieron registrándose ${ }^{54}$, con lo que se producían, ciertamente amortiguadas y de forma menos habitual, situaciones que recordaban a las ya apuntadas con los ciegos:

Cuando no hay guerra civil, ni política militante, y por consiguiente ni gacetas extraordinarias, ni hojas volantes, nuestro héroe saca del archivo un mazo de coplas, inventa sucesos horrorosos, hace que se ahorquen media docena de personas o se envenene una familia, degüellen

51 Ibid.

52 «Crónica general», La Dinastía (edic. de la tarde), 11 de diciembre de 1888. Mariano de Cavia se refería en una de sus «Crónicas momentáneas» (El Liberal, 28 de octubre de 1894) a los «timos callejeros» de los que eran responsables los «camelots a la madrileña», que «inventan títulos, fantasean sobre materias imaginarias, y pregonan con estentórea voz el nombre de quien jamás engendró tan contrahechas criaturas».

53 «Falsa noticia», La Dinastía, 29 de agosto de 1893.

54 Véase, sobre la venta del semanario España Monárquica, también en la Ciudad Condal, a principios de 1931: El Heraldo de Madrid, 12 y 14 de enero de 1931, 6 y 10 de febrero de 1931; La Libertad, 13 de enero de 1931, 13 de febrero de 1931. 
dos amantes desgraciados, o devore un lobo rabioso media población; y cualquiera de estos hechos que por supuesto acaba de ocurrir, sale de madrugada pregonándolo por los barrios bajos y plazuelas de la capital. $^{55}$

No se trataba en aquel caso de la venta de publicaciones periódicas, pero sí de «algún suceso raro acaecido el año del hambre» y presentado como noticia fresca por varios vendedores que se habían puesto de acuerdo. En esos momentos y después, lo que se pregona puede estar muy lejos de lo que contiene la publicación, pero responde a una lógica aprendida, a la experiencia en la venta y como oyente de lo que vocean otros vendedores, a lo que podría haber sido en coherencia con una amplia secuencia de informaciones y de relatos que jalonan la vida periodística.

\section{Un medio de comunicación, un engranaje de la información periodística}

La evolución de la venta al número en detrimento de las suscripciones se produce a lo largo del siglo XIX, en paralelo al auge de la producción impresa y adaptándose a la extensión del público lector, no restringido ya a las clases sociales de mayor poder adquisitivo a medida que avanza el tiempo. Los periódicos también se ven influidos por la nueva situación, modificando lentamente un aspecto externo en el que tendrán más cabida los elementos llamativos. A diferencia de lo que sucede con el suscriptor, que constituye en mayor medida un público cautivo, la venta al número se construye día a día. Es necesario llamar la atención del lector a través de la primera página.

De este modo el vendedor adquiere un singular poder. «El industrial en cuestión - afirmaba Manuel Ossorio y Bernard - ejerce una influencia decisiva en la suerte de las publicaciones periódicas y sus sentencias son inapelables; periódico despreciado por él morirá sin ser conocido por el público; periódico por él protegido alcanzará fama, fortuna e inmortalidad ${ }^{56}$. El quiosquero es «el árbitro supremo de la literatura del país», asegura Ricardo Aragó. ${ }^{57} \mathrm{Se}$ dan, en realidad, dos procesos de comunicación paralelos. El primero tiene como receptor a quienes acceden

\footnotetext{
55 Ferrer del Río y Pérez Calvo, 1844, p. 481.

56 Ossorio y Bernard, 2001, p. 98.

57 Aragó, 1917, pp. 89-90.
} 
al interior de la publicación. El segundo proceso, aunque a menudo preceda al primero, puede darse también de forma totalmente independiente, alcanzando a personas que escuchan las noticias o se detienen delante de imágenes y titulares sin por ello superar la barrera que supone la compra. Si la primera vía de comunicación hizo que se pusieran siempre en práctica numerosas medidas de control, la segunda despertó no pocas inquietudes y con ello la voluntad de reprimir sus posibilidades comunicativas específicas.

Pese a distintas normativas, los matices que los vendedores podían introducir espontáneamente en las noticias, por estos u otros medios, constituían un espacio que escapaba a los controles habituales. Hay que recordar que los vendedores actuaban por lo general al margen de la esfera de influencia inmediata de las empresas periodísticas, constituyendo una voz más dentro del proceso coral en el que pronto se convierte la comunicación. Una voz temida y singularmente libre que se situaba en un espacio no cartografiado, en una especie de tierra de nadie entre los privilegiados que tenían acceso a la escritura en la prensa y quienes ejercían labores de vigilancia sobre sujetos tan sensibles como la política, la religión o la moral.

Una voz que se introducía entre gobernantes y gobernados, imprescindible para mantener el contacto con estos últimos. De ahí que a partir de cierto momento, cuando los vendedores se vieron implicados en movimientos huelguísticos de alguna amplitud, se desplegaran importantes medios para contrarrestarlos. Cansinos-Assens se referiría a los vendedores ocasionales que surgieron durante la huelga de periodistas de 1919 como «redactores del propio periódico, señoritos afiliados a sociedades antisindicalistas, advenedizos del periodismo, esquiroles de afición». ${ }^{58}$ Efectivamente, $A B C$ y La Acción agradecieron la colaboración de cierto número de vendedores espontáneos - «muchísimos, innumerables caballeros» y «algunas señoritas», señaló $A B C-\mathrm{y}$ especialmente de los jóvenes mauristas y de Unión Ciudadana, ${ }^{59}$ guardia cívica legalizada poco tiempo antes que hizo de la ruptura de huelgas una de sus principales razones de ser.

Y en otros momentos no faltarían los voluntarios para desarrollar labores similares en la capital de España. Por ejemplo el 16 de noviembre de 1930, con Madrid inmerso en una huelga general, los únicos diarios publicados, $A B C$ y $E l$ Debate, fueron puestos a la venta, afirmaba la prensa,

\footnotetext{
58 Cansinos-Assens, 1921, p. 209.

59 Véase $A B C$ y La Acción, 11 de diciembre de 1919 y ss.
} 
por «jóvenes elegantemente vestidos y algunos vendedores habituales», siendo voceado el último diario en el centro de la ciudad durante algún tiempo por «elementos de la Juventud Católica y estudiantes católicos» ${ }^{60}$. En octubre de 1934 eran los jóvenes tradicionalistas, de Acción Popular y falangistas, y también los de Renovación Española y miembros del Partido Nacionalista Español quienes, según sus propias notas de prensa o los diarios afines, colaboraban en la venta de periódicos. Algunas de las organizaciones citadas no tardarían en hacer pública su «relación de servicios prestados» durante la huelga, entre los cuales figuraba la venta de prensa junto a la conducción de tranvías, limpieza, abastos, gas, electricidad.... Además, también se vendió prensa en comisarías y edificios oficiales, y el cierre de los quioscos durante los sucesos de octubre dio lugar a un prolongado conflicto tras declararse caducadas sus licencias, evidenciándose la relevancia de la cuestión también para los organismos oficiales. ${ }^{61}$

La prensa, que no existía realmente si no podía ser distribuida, se había convertido en un elemento fundamental de la lucha por el poder, pero también en un símbolo de cohesión y estabilidad a cuya presencia cotidiana toda la población estaba habituada. De ella emanaban interpretaciones del mundo y relatos que venían a poner orden en lo sucedido, jerarquizando informaciones y, mediante esta operación, haciendo que todo pareciera más comprensible. Su ausencia de las calles, suprimiéndose la comunicación entre los emisores habituales de mensajes y el público, no era un suceso anodino. Sin duda sería interpretada como una nueva demostración de fuerza de quienes aspiraban a modificar en profundidad el orden social establecido; tal vez como un adelanto del silencio al que las fuerzas rectoras de la sociedad podrían verse abocadas en el futuro. Y por ello ni determinadas organizaciones ni los organismos del Estado podían permanecer de brazos cruzados.

Esto iba acompañado del surgimiento de otros temores, no tanto por la fuerza de las huelgas (en un sector con trabajadores no cualificados y por lo tanto fácilmente sustituibles) como por la autonomía de los vende-

60 «Los periódicos que se han publicado. Varios incidentes», El Heraldo de Madrid, 17 de noviembre de 1930; «La jornada del domingo. Mucha animación y escasos incidentes», El Imparcial, 18 de noviembre de 1930.

${ }^{61}$ El Siglo Futuro y $A B C, 5$ y 6 de octubre de 1934 y ss. Sobre la actuación de las JAP, una nota de prensa posterior en: La Época, 13 de febrero de 1936. La venta de $A B C$ se había producido unos meses antes en gran medida por medios similares, con motivo de una huelga desencadenada contra Prensa Española. Véase: Iglesias, 1980, p. 265. 
dores, por lo que su despliegue representa de afirmación de una cultura de masas, mediática y popular, que no deja de ganar terreno, o por hacer más imprevisible que en el pasado el modo en el que se produciría la recepción de algunos mensajes. A medida que los mecanismos de comunicación se hacían más complejos era necesario movilizar a un número creciente de actores para imponer determinada visión de la realidad. Una red articulada de puntos de venta significa, en cierto modo, la existencia de una especie de juego de espejos que multiplica el efecto de las publicaciones y que contribuye a graduar la intensidad con la que determinados hechos son percibidos por el público.

Ciertamente, no hay noticia sin difusión mediática y las principales decisiones son adoptadas a otros niveles, pero en las personas que se dedican a la venta de prensa está uno de los indicadores más elocuentes de la relación que se produce entre lo que el público identifica como contenidos que hacen aumentar las ventas y las decisiones que se toman respecto a qué, cómo y dónde reflejará el periódico los distintos materiales de los que dispone para construir un relato de lo sucedido. Ningún otro de los sectores implicados en el negocio de la prensa suele expresar de forma tan neta la relación entre grandes acontecimientos y aumento de la venta. Como señala David Nasaw refiriéndose a los niños vendedores en Estados Unidos: sus sueños estaban hechos de asesinatos, guerras, desastres naturales... ${ }^{62}$

\section{Tendencias subversivas y pasiones humanas}

La venta de periódicos y revistas constituye una de las principales vías de difusión a gran escala del impreso y la cultura escrita. Pero, como hemos visto, la venta callejera no es considerada por muchos ni siquiera un oficio. Ello contrasta con el importante papel que las personas que se dedican a esta actividad desempeñan en las formas de comunicación desarrolladas en torno a la prensa. El vendedor ambulante pregona la cabecera y la información que contiene buscando el tono y el adjetivo adecuados, a veces desconociendo lo que vende tanto como la actualidad misma; deformando, pasando por el filtro de lo popular unos contenidos que en algunos casos, es necesario tenerlo presente, no pueden dejar de haber sido diseñados teniendo en cuenta estas circunstancias. Con todo, la destacada posición que

62 Nasaw, 1986, p. 77. 
ocupan los vendedores en el sistema informativo resulta molesta, provoca un rechazo que se expresa a menudo desde posiciones conservadoras. Tal vez por la fama que el vendedor tiene de ser «más liberal que Riego» y atribuírsele inclinaciones hacia «la república más roja ${ }^{63}$, por su propia condición extremadamente humilde o por difundir frecuentemente publicaciones consideradas indecorosas. Pero sin duda también porque contribuye a ampliar el círculo de aquellas personas que se forman una idea - por superficial que ésta sea- de lo que sucede en las altas esferas de gobierno, por provocar el debate de los más diversos asuntos en plena vía pública y por su capacidad agitativa en todo momento. ${ }^{64}$ Un reflejo de ello está en las numerosas actuaciones que tratan de restringir la venta en distintos momentos.

Los vendedores de periódicos disponen de un medio de comunicación con el público que, siendo indisociable de las propias publicaciones, disfruta de una notable autonomía. Son capaces de difundir elementos de la cultura escrita, haciéndolos visibles y audibles para una gran parte de la población, al tiempo que contribuyen a hacer de la prensa un elemento cotidiano de referencia en un espacio urbano que vive, cada vez más, al ritmo del diario. Vender periódicos es ocupar el terreno y por lo tanto entrar en competencia con otros actores presentes en el espacio público. Ello es muy visible en el caso de la venta militante, planteada a veces como un auténtico desafío, pero está presente también cuando se practica una venta puramente pecuniaria. En este último caso la presencia en la calle del vendedor y su mercancía están igualmente llenos de significado. Por una parte la persona que se dedica a la venta de prensa es una encarnación palpable y cotidiana, más visible que cualquier otro protagonista relacionado con el periodismo, de un mundo nuevo en el que la prensa, la opinión pública y la participación ciudadana deben jugar un papel esencial; un mundo que en nada se parece al del pasado. En otro plano, el vendedor también desempeña un papel democratizador importante al dejar en sus mensajes una impronta popular que a menudo distorsiona el contenido original. Su visión de aquello que refleja el diario está, además, totalmente sesgada por el interés económico que le mueve, destacando mediante el voceo lo que considera que hará aumentar la venta (generalmente críme-

63 Ossorio y Bernard, 2001, p. 100; Sepúlveda, 1872, p. 47. El último autor se detiene en el carácter superficial del republicanismo que atribuye a los vendedores («no conocen lo que defienden») y en su oportunismo cuando media la posibilidad de «ganar algunos cuartos».

${ }^{64}$ Una situación similar mucho tiempo antes, en relación con los ciegos vendedores de relaciones de sucesos y otros impresos, descrita en: Iglesias Castellano, 2017. 
nes, crisis políticas, acontecimientos taurinos y más adelante deportes) y conformando una visión particular de lo que ha sucedido.

A la selección de contenidos propia del diario se añade un nuevo sesgo que produce una visión del mundo en la que están extraordinariamente sobrerrepresentados determinados fenómenos. Con estos y otros mimbres, dependiendo del acceso a fuentes de información más variadas, los ciudadanos construyen las representaciones de la sociedad en la que viven. Por ello es necesario afrontar la comunicación periodística como un proceso complejo en el que intervienen múltiples voces, actores fundamentales que reclaman su lugar en una historia del periodismo abierta a las manifestaciones visuales y orales que se generan en torno al mismo.

Quizás porque muchos vendedores profesionales se sintieran atacados desde posiciones conservadoras se inclinaran instintivamente a la izquierda. Presentados con sombríos trazos por vender publicaciones alegres y comerciar con las «pasiones humanas», los profesionales de la venta trataron de eludir responsabilidades en este sentido ${ }^{65}$ En todo caso, la orientación señalada se refleja en distintos escritos, en las tareas de carácter militante que se desarrollaron en determinados puntos fijos de venta, o en la inequívoca adscripción de algún vendedor conocido, como Ángel Chueca, uno de los protagonistas de la sublevación que tiene lugar en Zaragoza a principios de 1920, retratado con detalle por Ramón J. Sender en Crónica del Alba y al que también alude en sus memorias José Luis Galbe Loshuertos. ${ }^{66}$ Que un puesto de periódicos podía convertirse en un excelente punto de observación y en una atalaya desde la que incidir en el entorno parece bastante claro. Se trata, no obstante, de saber si la adscripción ideológica que en algunas fuentes de época se atribuye a la mayoría de los vendedores puede confirmarse, de ser así, los motivos, y especialmente - se corresponda esto o no con la realidad - cómo influye esta imagen en la percepción de la venta y los vendedores, en la configuración de representaciones en torno a los mismos.

65 Ello implica una perspectiva muy diferente, poniendo en primera línea al vendedor, como hace Ricardo Aragó (1917, especialmente, pp. 88-90), o presentándolo implícitamente como un simple canal por el que circula aquello que se produce en otros ámbitos, por ejemplo cuando la Asociación de vendedores de periódicos de Barcelona trata de lograr que las empresas implicadas suscriban un acuerdo haciéndose responsables de multas, daños y perjuicios de los socios (Libro de Actas de la Junta Directiva, 2-7, 20-8 y 3-91923, AGGCE, PS-Barcelona, C. 1353, Exp. 2).

66 Sender, 1971; Galbe Loshuertos, 2011, pp. 62 ss. La visión que ofrece la prensa de lo sucedido y del vendedor de periódicos puede seguirse en distintos diarios, como $E l$ Globo o El Sol, a partir del 10 de enero de 1920. 


\section{Conclusiones}

Esta última perspectiva tendrá que ser fundamental en estudios futuros sobre la distribución de la prensa. Toda sociedad dotada de un sistema comunicacional moderno cuenta con representaciones del mismo, que se materializan en obras literarias, grabados, caricaturas, fotografías, películas, historietas, letras de canciones, objetos publicitarios, textos periodísticos, etc. Los reporteros, colaboradores y en general quienes por distintos motivos conocieron en algún momento las entrañas de una redacción juegan en estos casos un importante papel, contribuyendo a menudo a su puesta en escena y difundiendo también en gran medida una determinada visión del resto de protagonistas del sistema: tipógrafos, linotipistas, administradores, repartidores, cerradores, corredores, vendedores... Es decir, todos aquellos que no disponen de acceso directo a la difusión de su punto de vista mediante la escritura en el periódico, ni como el director o el propietario, de poder directo sobre lo escrito. Los redactores y reporteros producen descripciones particularmente cercanas al mundo de la distribución, pero no por ello menos externas a sus protagonistas. Si cuando el periodista se representa a sí mismo deben considerarse los factores que distorsionan la imagen proyectada, existiendo, como sucede siempre, alguna distancia entre la representación y lo representado, cuando se trata de recoger lo esencial de una ocupación distinta suele entrar en juego un cierto grado de desconocimiento de la realidad, agravada además por la autoridad que el periodista cree tener en todo lo relativo al mundo del periodismo.

De aquí nace una visión miserabilista de la venta de prensa, contemplada en las páginas precedentes a partir de las fuentes citadas. Se trata de una percepción que - por más que la venta atrajera a personas con pocos medios y aptitudes - debe ser matizada, entre otras cosas porque la situación evoluciona con el tiempo. A los vendedores se les considera corruptores de la sociedad o falsificadores de la realidad y se les atribuyen otras características negativas: son carroñeros, insensibles, tramposos, mentirosos... desean que se produzca, por ejemplo, una gran catástrofe o un crimen sensacional para vender más mercancía. ${ }^{67}$ Se produce todo un proceso de condenación que en un primer acercamiento puede relacionarse con la configuración de la venta de prensa como un factor

67 Véase: Rodríguez Infiesta, 2011. 
capaz de modificar el imaginario colectivo. En este y otros contextos la presencia abundante de periódicos actúa como un epítome de la modernidad urbana. ${ }^{68}$

Uno de los desafíos de la investigación en torno a la historia de la distribución estará sin duda no solamente en un mejor conocimiento de las condiciones materiales de trabajo, los conflictos laborales o, por ejemplo, las medidas legislativas. Será importante también profundizar en distintas representaciones y relatos, en los que van sedimentándose visiones ficticias que acaban condicionando de algún modo la mirada de los propios protagonistas. Ciertamente, no existe cultura mediática sin puesta en escena de esta cultura mediática, ni diario sin representación del diario ${ }^{69}$ pero no es menos cierto que los medios mantienen una relación de dependencia con la distribución, y que ésta engendra representaciones que inciden en la percepción general del espacio mediático. Las propuestas en torno al análisis del imaginario mediático surgidas en los últimos años en Canadá o EE.UU. son una excelente muestra de las posibilidades de este enfoque, aunque la atención se haya centrado hasta ahora preferentemente en los periodistas. ${ }^{70}$ Ello es compatible con un acercamiento global al periodismo y el desarrollo de una historia sociocultural de la prensa que analice los recursos que permiten a las publicaciones periódicas generar adhesiones y edificar identidades, hasta convertirse en un actor político de primer orden.

En un marco global que puede definirse aludiendo al triunfo de la periodicidad y el flujo mediático, características de lo que se ha definido como civilización del diario ${ }^{71}$, la práctica de la venta callejera aparece vinculada a situaciones de subordinación social. En estas páginas se ha optado por poner el foco en determinadas características de esta ocupación, abarcando un periodo de tiempo relativamente amplio, lo que no significa ignorar un rico proceso de transformaciones históricas en la prensa española, desde los contenidos a la manera de presentarlos, la or-

68 Cfr.: Dorn y Vogel, 2001, p. 77.

69 Pinson, 2012a.

70 Es imprescindible la iniciativa The Image of the Journalist in Popular Culture Project (IJPC), vinculada a la Universidad del Sur de California, donde se ha desarrollado un importante proyecto que incluye una base de datos, un archivo y, entre otras cosas, una revista académica, The IJPC Journal. De los resultados que pueden alcanzarse en este terreno tenemos valiosos ejemplos en las monografías de Ehrlich y Saltzam, 2015, y Pinson, $2012 b$.

71 Véase: Kalifa y Vaillant, 2004 ; Kalifa, Régnier y Thérenty, 2011. 
ganización del trabajo, la maquinaria, los salarios, las tiradas, etc. Todo ello tiene mayor o menor incidencia en la esfera de la distribución. Lo interesante - por ello se ha elegido organizar de este modo la documentación manejada - es que las representaciones del mundo de la venta de periódicos evolucionan mucho más lentamente, conservándose a menudo la referencia a la marginación del vendedor, pero mitigada por una evolución que los mismos protagonistas de esta historia reconocen, relegándola a veces a un pasado que sin embargo sigue vivo en el imaginario mediático. Es un proceso que empieza a percibirse más claramente en torno al cambio de siglo y que se acentúa en el primer tercio de la nueva centuria, cuando fenómenos ligados a la urbanización, la alfabetización, la modernización en definitiva, apuntan en España hacia una sociedad de masas.

La fuerza de la venta callejera está en la posibilidad de influir en el público a través de diferentes vías. Los grabados, fotografías, caricaturas de la publicación, pero también mediante la percepción del periódico como objeto en sociedad y del vendedor como actor en la escena pública; gracias a la lectura, ya sea de los titulares expuestos en el espacio urbano o de una lectura más reposada de los contenidos del periódico; y por medio del lenguaje sonoro, oralmente por lo común. Tres esferas que pueden solaparse, complementarse, reforzarse, contradecirse, actuar sobre un mismo receptor o independientemente sobre distintas personas, combinándose de maneras distintas, con efectos diversos. En cierto modo el vendedor pone esta capacidad de influencia diversificada, perceptible a través de las representaciones, al servicio de la ocupación del terreno urbano, ya sea por la prensa y lo que ésta representa globalmente o por la ideología que encarna determinada publicación.

Al mismo tiempo quienes se ocupan de la venta se apartan de la función a la que las autoridades públicas tratan una y otra vez de reducirles: ser simples vehículos del equilibrio de influencias que encarna la prensa y del orden del que ésta emana. El vendedor es un furtivo que se adentra en tierras que pertenecen a otros. Su lectura - al contrario de la escritura plasmada en el periódico - es efímera y deja pocos rastros, pero supone casi siempre un toque popular y, particularmente cuando entra en juego el voceo de noticias, el principal momento en el que los sectores desfavorecidos de la población contribuyen a dotar de significado al periódico de gran tirada antes de la venta, teniendo la última palabra en un momento crucial. El vendedor actúa en un terreno que sabe que no le pertenece, pero convencido de que tampoco le es totalmente ajeno. Un poco pregonero, o guarda de coto y al mismo tiempo furtivo, el vendedor es un 
elemento imprescindible cuya insignificancia no deja de recordarse una y otra vez mediante múltiples representaciones, como si la misma naturaleza de su oficio supusiera un peligro permanente.

\section{Fuentes}

Archivo General de la Villa de Madrid.

Archivo General de la Guerra Civil Española, Salamanca.

\section{Fuentes hemerográficas}

$\mathrm{ABC}$

La Acción

Alrededor del Mundo

Boletín Oficial de Madrid

Boletín de la Sociedad de Vendedores de Periódicos El Progreso

La Correspondencia de España

Crónica

La Dinastía

La Gaceta Literaria

El Globo

El Heraldo de Madrid

La Ilustración Española y Americana

El Imparcial

La lectura dominical

El Liberal

La Libertad

Nuevo Mundo

El País

El Siglo Futuro

El Sol

La Voz

\section{Bibliografía}

Aguilar, Manuel, Una experiencia editorial, Madrid, Aguilar, 1972, 2 vol.

ARAGó, Ricardo, El kiosco, El Amigo de la Juventud, Barcelona, 1917.

Baroja, Pío, La Busca, Caro Raggio, Madrid, 1973 [1904]. 
Botrel, Jean François, «La difusión de Madrid Cómico, 1886-1897», en Carmen SAlaün SÁnchez (dir.), Presse et public, Rennes, Université de Rennes 2 Haute Bretagne, 1982, pp. 21-40.

Botrel, Jean-François, Libros, prensa y lectura en la España del siglo XIX, Madrid, Fundación Germán Sánchez Ruipérez / Pirámide, 1993.

Botrel, Jean-François, «Les aveugles colporteurs en Espagne : un vecteur original de propagande», en Maurice CARREZ, Thomas BoucheT (dirs.), Le verbe et l'exemple. Colporteurs et propagandistes en Europe de la Révolution française à nos jours, Territoires contemporains. Cahiers de l'IHC, n. ${ }^{\circ} 5$, 2000, pp. 84-99.

Botrel, Jean-François, «Mercado y lectores de la prensa en España», en Celso Almuiña y Eduardo Sotillos (coords.), Del Periódico a la Sociedad de la Información (I), Madrid, España Nuevo Milenio, 2002, pp. 111-126.

Botrel, Jean-François, «Los analfabetos y la cultura escrita (España, siglo XIX)», en Castillo Gómez, Antonio (coord.), Culturas del escrito en el mundo occidental: del Renacimiento a la contemporaneidad, Madrid, Casa de Velázquez, 2015, pp. 251-267.

CAnsinos-Assens, Rafael, La huelga de los poetas, Editorial Mundo Latino, Madrid, 1921.

Certeau, Michel de, L'invention du quotidien. 1. Arts de faire, Gallimard, 1990.

Díaz Cañabate, Antonio., Memorias de un vendedor de periódicos. Conferencia leída el día 2 de mayo con motivo del Cincuentenario de la Hemeroteca Municipal de Madrid, Artes Gráficas Municipales, Madrid, 1968.

Dorn, Margit y Vogel, Andreas, Geschichte des Pressevertriebs in Deutschland, Nomos, Baden-Baden, 2001.

Ehrlich, Matthew C. y SAltzam, Joe, Heroes and Scoundrels: The Image of the Journalist in Popular Culture, University of Illinois Press, Champaign, 2015.

Escolano Benito, Agustín (dir.), Leer y escribir en España: doscientos años de alfabetización, Fundación Germán Sánchez Ruipérez, Madrid, 1992.

Feliu García, Emilio y Fernández Poyatos, M. ${ }^{a}$ Dolores, «El Gratis (18421843). Aproximación al estudio de un periódico innovador», Estudios sobre el mensaje periodístico, n. ${ }^{\circ}$ 18, 2012, pp. 721-737.

FERnÁNDEZ, Pura, «El estatuto legal del romance de ciego en el siglo XIX: a vueltas con la licitud moral de la literatura popular», en Luis DíAz G. ViAnA (coord.), Palabras para el pueblo. Vol. I. Aproximación general a la Literatura de Cordel, CSIC, Madrid, 2000, pp. 71-120.

Fernández Poyatos, M. a Dolores y Feliu García, Emilio, «Avisos, anuncios, reclamos y publicidad en España. Siglos XVIII y XIX», Ámbitos. Revista internacional de comunicación, $\mathrm{n}^{\circ}$ 21, 2012, pp. 315-332.

Ferrer del Río, Antonio y PÉREZ CALVo, Juan, «El ciego», en: VV.AA., Los españoles pintados por sí mismos, J. Boix Editor, Madrid, 1844 (t. II), pp. 472-482. 
Galbe Loshuertos, José Luis, La justicia de la República. Memorias de un fiscal del Tribunal Supremo en 1936, Marcial Pons, Madrid, 2011.

GÁrate CóRdobA, José María, Mil días de fuego. Memorias documentadas de la guerra del treinta y seis, Caralt, Barcelona 1972.

GómeZ MOMPART, Josep Lluis, La gènesi de la premsa de masses a Catalunya (1902-1923), Barcelona, Pórtic, 1992.

GonZÁleZ de TeJAdA, J., La nueva España, Imprenta de S. Landáburu, Madrid, 1872.

GONZÁLEZ JURADO, Deborah, «El papel del ferrocarril en la distribución de prensa y publicidad entre 1865 y 1941. El caso de la Compañía de los Ferrocarriles de Madrid a Zaragoza y Alicante, y algunos antecedentes», Tst, Transportes, Servicios y Telecomunicaciones, n. $^{\circ}$ 27, 2014, pp. 64-94.

GonZÁlez JuRAdo, Deborah, Comunicación, publicidad y modernidad. El caso de eje ferroviario Madrid, Córdoba, Málaga (1848-1900), Universidad de Málaga, Facultad de Ciencias de la Comunicación, 2015. https://riuma.uma. es/xmlui/bitstream/handle/10630/13757/TD_GONZALEZ_JURADO_Deborah.pdf?sequence $=1$ [con acceso el 8 de marzo de 2019].

GuHA, Ranajit, «Preface», en Ranjit GuHA y Gayatri ChaKravorty SPIVAK (eds.), Selected Subaltern Studies, Nueva York, Oxford University Press, 1988, p. 35-36.

GutiÉRREZ, Florencia y GANTús, Fausta, «Los pequeños voceadores: Prácticas laborales, censura y representaciones a finales del siglo XIX», en Carlos Illades y Mario BARBOSA CRUZ (coords.), Los trabajadores de la ciudad de México, 1860-1950: textos en homenaje a Clara E. Lida, El Colegio de México/ Universidad Autónoma Metropolitana, México D.F, 2013, pp. 81116.

HÉGARAT, Thibault Le, «L'histoire des médias, un sous-champ de l'histoire culturelle?», en Claire Blandin, François RoBInEt, Valérie ScHAFER, Penser l'histoire des médias, Paris, CNRS Éditions, 2019, pp. 131-137.

IGLESIAS, Francisco, Historia de una empresa periodística. Prensa Española, editora de ABC y Blanco y Negro (1891-1978), Editorial Prensa Española, Madrid, 1980.

IGLESIAS, Francisco, «Factores históricos de la consolidación de la empresa periodística y las grandes tiradas», Comunicación y estudios universitarios (Valencia), n. ${ }^{\circ}$ 6, 1996, pp. 25-32.

Iglesias CASTEllano, Abel, «El ciego callejero en la España moderna: balance y propuestas», LaborHistórico, Vol. 2, n. ${ }^{\circ}$ 1, enero-junio 2016, pp. 74-90. https://revistas.ufrj.br/index.php/lh/article/view/4809/3517 [con acceso el 25 de enero de 2019].

Iglesias CASTEllano, Abel, «Los ciegos: profesionales de la información. Invención, producción y difusión de la literatura de cordel (siglos XVI-XVIII)», en Giovanni CIAPPELli; Valentina Nider (coords.), La invención de las noticias: las relaciones de sucesos entre la literatura y la información (si- 
glos XVI-XVIII), Trento, Università degli Studi di Trento-Dipartimento di Lettere e Filosofia, 2017, pp. 467-489.

INFANTES, Víctor; lópez, François; BotRel, Jean-François (dirs.), Historia de la edición y la lectura en España, 1472-1914, Madrid, Fundación Germán Sánchez Ruipérez, 2003.

Kalifa, Dominique y Vaillant, Alain, «Pour une histoire culturelle et littéraire de la presse française», Le Temps des Médias, 2004/1, n. ${ }^{\circ}$ 2, pp. 197-214.

Kalifa, Dominique ; RÉGnier, Philippe ; Thérenty, Marie-Éve ; VAILlant, Alain (dirs), La civilisation du journal. Histoire culturelle et littéraire de la presse française au XIX $X^{e}$ siècle, Nouveau Monde Éditions, Paris, 2011.

MARINÉ, Enrique, Cómo se administra un gran diario, Madrid, CIAP, 1929.

Martínez Fernández, Valentín Alejandro, Historia de la distribución de la prensa, Diputación Provincial de A Coruña, A Coruña, 2000.

Martínez Martín, Jesús A. (dir.), Historia de la edición en España 1836-1936, Madrid, Marcial Pons, 2001.

Martínez MARTín, Jesús A., «La lectura en la España contemporánea: lectores, discursos y prácticas de lectura», Ayer, n. ${ }^{\circ}$ 58, 2005, pp. 15-34.

MARTínez Rus, Ana, «Libros en los andenes. La sociedad general de librería y los ferrocarriles», en Actas del III Congreso de Historia Ferroviaria, Gijón, 2003, 13 pp. http://www.docutren.com/HistoriaFerroviaria/Gijon2003/pdf/ te5.pdf [con acceso el 18 de enero de 2019].

Nasaw, D., Children of the City: At Work and at Play, Oxford University Press, New York, 1986.

ORY, Pascal, L'Histoire Culturelle, Paris, PUF, 2007 (2. edic).

Ossorio y Bernard, Manuel, Viaje Crítico alrededor de la Puerta del Sol, Castalia / Comunidad de Madrid, Madrid, 2001, edic. María Isabel Jiménez Morales [1. ${ }^{\text {a }}$ edic. 1874 y 1882 ].

PINSON, Guillaume, «L'imaginaire médiatique. Réflexions sur les représentations du journalisme au XIX $X^{\mathrm{e}}$ siècle», Contextes, . $^{\circ}$ 11, 2012a. https://journals. openedition.org/contextes/5306 [con acceso el 28 de mayo de 2019].

Pinson, Guillaume, L'imaginaire médiatique. Histoire et fiction du journal au XIXe siècle, Classiques Garnier, Paris, 2012b.

RODRÍGUEZ INFIESTA, Víctor, «Misère et grandeur d'un métier. Les crieurs de journaux dans l'Espagne contemporaine», Mélanges de la Casa de Velázquez, t. 41, n. $^{\circ} 2,2011$, pp. $205-221$.

RODRÍGUEZ INFIESTA, Víctor, «Quioscos y puestos de venta de prensa en Madrid y otras ciudades españolas hasta la Guerra Civil. La emergencia de un nuevo agente de comunicación social», Mélanges de la Casa de Velázquez, t. 46, n. ${ }^{\circ}$ 2, 2016, pp. 239-257.

ROJAS FlORES, Jorge, Los suplementeros: los niños y la venta de diarios. Chile, 1880-1953, Ariadna Ediciones, Santiago de Chile, 2006.

Sender, Ramón J., Crónica del alba, t. 2, Alianza, Madrid, 1971 [1942-1966]. 
Seonne, María Cruz, Historia del periodismo en España 2. El siglo XIX, Alianza, Madrid, 1983.

SEPÚlVEDA, Ricardo, «El vendedor de periódicos», en Los españoles de ogaño, t. I, Librería de Victoriano Suárez, Madrid, 1872, pp. 39-49.

TARTILÁn, Sofía, Páginas para la educación popular, Imprenta de Enrique Vicente, Madrid, 1877.

TENTI, María Mercedes, «Los Estudios Culturales, la Historiografía y los sectores subalternos», Trabajo y Sociedad, n. ${ }^{\circ}$ 18, vol. XV, 2012, pp. 317-329.

ThÉRENTY, Marie-Ève, «Vivre au rythme du journal », en KALIFA, Dominique ; RÉGNIER, Philippe ; ThÉRENTY, Marie-Éve ; VAILlANT, Alain (dirs), La civilisation du journal. Histoire culturelle et littéraire de la presse française au XIX ${ }^{\mathrm{e}}$ siècle, Nouveau Monde Éditions, Paris, 2011, pp. 1309-1317.

Vilanova Ribas, Mercedes y Moreno Juliá, Xavier, Atlas de la evolución del analfabetismo en España de 1887 a 1981, Ministerio de Educación y Ciencia, Madrid, 1992.

\section{Datos del autor}

Víctor Rodríguez Infiesta es profesor del Área de Historia Contemporánea de la Universidad de Oviedo. La mayoría de sus libros como autor o coordinador, capítulos de libro y artículos se centran en la historia de la prensa contemporánea, especialmente en los mecanismos de socialización política y campañas de autopromoción, ocupándose más recientemente de las relaciones entre prensa y opinión pública, así como de la historia de la distribución de la prensa y de la propaganda en la Francia de entreguerras. 